\title{
Metabolic and mineral conditions of retained placenta in highly productive dairy cows: pathogenesis, diagnostics and prevention - a review
}

\author{
Ryszard Mordak ${ }^{1}$, Józef Nicpoń ${ }^{1}$, Josef Illek ${ }^{2}$ \\ ${ }^{1}$ Wrocław University of Environmental and Life Sciences, Faculty of Veterinary Medicine, \\ Department of Internal Diseases with Clinic for Horses, Dogs and Cats, Wrocław, Poland \\ ${ }^{2}$ University of Veterinary and Pharmaceutical Sciences, Faculty of Veterinary Medicine, \\ Large Animal Clinical Laboratory, Brno, Czech Republic
}

Received November 29, 2016

Accepted October 2, 2017

\begin{abstract}
The time around calving in highly productive dairy cows is a critical period in terms of their metabolism, which is connected with high demands of the foetus as well as with the onset of lactation. Retained placenta in cows may have multifactorial aetiology, but in herds which are free from infectious diseases, the most important reasons are; periparturient metabolic changes and disturbances to the internal balance and stress. During the periparturient period, the most important factor causing immune suppression and hypotony of uterus in cows is metabolic stress due to hormonal and nutritional factors, including metabolic fluctuations, negative energy balance, as well as shortage of proteins, minerals, vitamins and antioxidants. This metabolic stress as a result of an imbalance in the internal metabolic homeostasis activates the hypothalamicpituitary-adrenocortical axis (HPA) and increases serum corticosterid (cortisol) concentration, especially on the day of calving. Cortisol is a powerful immune suppressive factor that causes depression of leukocyte proliferation and their functions. The periparturient metabolic stress may also stimulate the production of catecholamines, especially adrenalin. Elevated levels of adrenalin activate adrenoreceptors of the myometrium, which in turn cause hypotony or atony of the uterus at calving in cows. Elevated levels of cortisol and adrenalin may significantly inhibit the rejection and expulsion of foetal membranes in cows, resulting in an increased incidence of their retention. These important mechanisms for placental retention in highly productive dairy cows often have primary nutritional metabolic aetiology, but they also occur during secondary metabolic disturbances and metabolic stress during calving. This metabolic and immunological aetiology and pathogenesis of retained placenta usually occur in highly productive periparturient cows on dairy farms in the absence of bovine infectious diseases, which can couse placentitis, stillbirth and the infectious origin of foetal membrane retention. The paper presents the most important metabolic, mineral and immunological disturbances as conditions for retained placenta in dairy cows. It also shows different methods of herd monitoring, important examples of clinical and laboratory diagnostics, and methods of nutritional and veterinary prevention of this health problem in dairy cows.
\end{abstract}

Cattle, nutrition, metabolism, periparturient stress

\section{Metabolic and mineral aetiology and pathogenesis of retained placenta in cows}

The time around calving is a critical period in high-yielding cows with regard to hormonal changes, metabolism, immunity, health, further fertility, and milk productivity (Goff and Horst 1997; Sobiech et al. 2010; Wathers 2010; LeBlanc 2013). During this time, the immune system is depressed in periparturient cows (LeBlanc et al. 2004; Goff 2008). The cited authors have presented significant correlations between immune suppression and deficiency of energy, proteins, minerals, vitamins, antioxidants, and physical effective neutral detergent fibre (peNDF) in high yielding cows. During the transition period in high yielding cows, the major cause of impairment of their immune system is the periparturient stress caused by hormonal and metabolic fluctuations, in particular, a negative energy balance, lack of minerals, antioxidants, and vitamins associated with the demands of

Address for correspondence:

Ryszard Mordak

Department of Internal Diseases with Clinic for Horses, Dogs and Cats

Faculty of Veterinary Medicine

Wrocław University of Environmental and Life Sciences

Grunwaldzki 47, 50-366 Wrocław, Poland 
a mature foetus, and the onset of lactation (LeBlanc et al. 2004; Mee 2004; Goff 2006; Spears and Weiss 2008; Wathers et al. 2013; Esposito et al. 2014). By stimulating the production of the corticotrophic releasing hormone $(\mathrm{CRH})$ and the adrenocorticotrophic releasing hormone $(\mathrm{ACTH})$, this metabolic stress activates the hypothalamic-pituitary axis (HPA) and as a consequence increases the plasma cortisol level from its mean baseline concentrations around $5 \mathrm{ng} / \mathrm{ml}$ to $10-20 \mathrm{ng} / \mathrm{ml}$ observed in different metabolic disturbances by Mormede et al. (2007), and even more (5-7 × increase) in hypocalcaemic cows as reported by Horst and Jorgensen (1982). Also newer publications show a novel hypothesis for immune-mediated aetiology of mineral disturbances observed especially during hypocalcaemia - milk fever in dairy cows (Kimura et al. 2006; Gray et al. 2007). Cortisol is a powerful immune-suppressive factor that reduces the leukocyte proliferation and fundamental functions, and does not allow for the normal, efficient maternal immune recognition and rejection of foetal membranes with trophoblast cells as an allogeneic tissue for cows (Davies et al. 2004). The important relationship between neutrophil functions and periparturient disorders in cows was also shown by other researchers Cai (2002). During periparturient stress, production of catecholamines, especially adrenaline, is elevated. For example, the mean concentration of adrenaline in periparturient heat-stressed cows was determined to be around $80 \mathrm{pg} / \mathrm{ml}$, whereas in thermo-neutral cows, its mean level was observed to be around $60 \mathrm{pg} / \mathrm{ml}$ (Lamp et al. 2015). Adrenaline stimulation of myometrial adrenoreceptors causes hypotony or atony of the uterus and may cause dystocia. Dystocia accompanying metabolic disturbances, veterinarian's interventions and other negative factors during calving can act as an additional stressor and can increase the levels of cortisol and immune suppression in cows (Civelek et al. 2008; Beagley et al. 2010). Thus immune-suppression and hypomotility of the uterus may be dangerous for normal parturition, expulsion of the foetus and normal separation and rejection of placenta in cows (Joosten and Hensen 1992; Miyoishi et al. 2002; Esposito et al. 2014).

When analyzing the results of a more detailed scientific study during the transition period in cows with immune suppression, the proliferation of leukocytes was found to be severely depressed (Trevisi et al. 2012). Moreover, the important functions of leukocytes such as the ability to aggregate and phagocytosis of neutrophils, cytotoxic activity of lymphocytes, as well as production of chemotactic cytokines (interleukin IL-8) activating these leukocytes, are reduced during this period (Kimura et al. 1999). The cited authors showed that in the immunological mechanism of retained placenta (RP) there is an important role for the chemotactic factor IL-8 of leukocytes, which are found in the placentomes of cows with normal placental separation but are absent in placentomes of cows with retention of foetal membranes. In addition, blood leukocytes, especially neutrophils of cows with $\mathrm{RP}$, are less reactive to chemotactic stimuli than in cows with normal placental rejection. In another research, Kimura et al. (2002) observed the plasma IL-8 concentration to be lower in cows with RP (mean $51 \mathrm{pg} / \mathrm{ml}$ ) than in cows expelling the placenta at term (mean $134 \mathrm{pg} / \mathrm{ml}$ ). Thus, depressed neutrophil function is a major reason for development of $\mathrm{RP}$ in dairy cows. Under these unfavourable conditions, the normal efficient maternal immune response and expulsion of foetal membranes in cows is impaired, resulting in their retention (Kimura et al. 2003). Moreover, the cited authors suggested that depressed production of chemotactic cytokine IL-8 may be an important factor affecting neutrophil functions in the development of placental retention in cows. The ability of neutrophils to recognize foetal (foreign - trophoblast) cotyledon tissue was measured with the use of chemotaxis assay as well as neutrophil killing ability, which was estimated by determining myeloperoxidase activity. Neutrophil myeloperoxidase was reduced in periparturient cows, especially during subclinical or clinical milk fever (Kimura et al. 1999; Kimura et al 2006). In cows with RP, decreased phagocytic activity of macrophages was also noted by Miyoshi et al. (2002). Results of cited studies indicate that there are major functional 
differences in placental neutrophils and macrophages between normally calving cows and cows with the retention of foetal membranes.

Current knowledge shows that the pathogenesis of placental retention in high-yielding cows depends of their efficient immunity. During normal calving with normal time for the expulsion of placenta (less than 12-24 h, usually determined in practice up to $12 \mathrm{~h}$ after birth of foetus), maternal immunological recognition of foetal antigens (major histocompatibility complex - MHC class I proteins) expressed by trophoblast cells triggers an immune-inflammatory response which leads to effective separation and rejection of the foetal membranes with their foetal part as a foreign tissue, similar to the effects of anallogeneic transplant (Davies et al. 2004; 2006). During periparturient stress, cortisol decreases the ability of expression of MHC class I molecules and the production of prostaglandins and prostacyclins, which has been observed in cows with RP (Horta et al. 1986; Hill et al. 2002). Also the anatomical cotyledonary and synepitheliochorial structure of the placenta as well as its degree of maturity during parturition or abortion may have a major influence on the incidence of RP in cows (Schlafer et al. 2000; Martins et al. 2004; Peter 2013). Placental maturation with the occurrence of adequate number of trophoblastic binucleate cells which can migrate and fuse with endometrial epithelial cells forming trinucleate hybrid cells as a foeto-maternal syncytium shortly before calving is especially important for the immunological recognition and rejection of foetal membranes (Wooding 1992; Schlafer et al. 2000; McNaughton and Murray 2009). The foetal trophoblast MHC class I peptides originating from destructed trophoblast cells during calving or abortion should be adequately (numerically and functionally) represented for the maternal immunity system and they should effectively provoke an attack by the maternal cytotoxic T-lymphocytes, monocytes, macrophages, phagocytic neutrophils and other leukocytes Davies et al. (2006). Activated leukocytes with the use of their cytokines cause a typical immune-inflammatory reaction on allogeneic trophoblast tissue, relative to the degree of maturity of the placenta, and also to the level of maternal immunity in cows (Saito 2001; Price et al. 2015; Jahan et al. 2015). More aspects of discussed topics involving immunological mechanisms with cytokine regulations, which may act during the periparturient period in relation to RP has been also reviewed lately Mordak and Stewart (2015).

\section{Diagnostics of metabolic and mineral conditions in periparturient cows}

In herds of high yielding cows which are at low risk of infectious diseases, the most important pathogenic factor causing RP during parturition is immune suppression caused by metabolic disorders. These metabolic conditions and health effects are adequately connected with high milk production in cows (Goff 2008). In cases with few metabolic and immune problems, the clinical cases of RP are observed in a low percent of cows in the herd. However, in cases where the level of immune-suppression is higher, RP is often observed in above $10 \%$ cows in the herd. In the European Union, the incidence of RP is noted in around 10\% dairy cows (Suthar et al. 2013) and it is usually the third most important health problem on farms following mastitis and lameness. The incidence of RP in dairy cows can also be a marker of metabolism efficiency around the time of parturition in the herd, where the problem of infectious diseases involving reproductive tract is not present. Almost all high-yielding cows experience some degree of reduced feed intake, negative energy balance, insulin resistance, hypocalcaemia and reduced immune function during the transition period. The various methods of clinical monitoring of health involving the level of milk production, feed intake, body condition scoring, reproductive health indicators, percentage of cases of RP in the herd as well as different laboratory tests of blood and other samples, should be performed before and after calving in dairy cows (LeBlanc 2013). According to the quoted author the monitored prepartum increase in 
serum concentration of non-esterified fatty acids (NEFA) above $0.4 \mathrm{mmol} / \mathrm{l}$ in $7-10$ days before expected calving is associated with an increased risk of RP and other postpartum health problems in cows. Other research showed that in highly productive cows with precalving serum NEFA concentration above $0.3 \mathrm{mmol} / 1$, RP was to be twice as likely observed (odds ratio $=1.8$ ) in comparison to cows with a more balanced indicator (Chapinal et al. 2011). Diagnostic systemic laboratory monitoring of blood or milk ought to be performed in the representative group of cows (around 10\% animals or not less than 7 samples from adequate technological groups of cows: usually a week before, a week after parturition, and during the later lactation period (Whitaker et al. 2005; Nordlund 2005; Mordak and Nicpoń 2006; Wathers 2010). Different metabolic and mineral disorders may be observed before and during calving as risk factors of RP in highly productive dairy cows (Trevisi et al. 2008). In cows with RP, disturbances to liver functions have also been diagnosed (Semacan 2005). Thus, cows at risk of RP of metabolic origin can be diagnosed with the use of various biochemical properties of the blood, such as increased levels of hepatic enzymes, lipid metabolites such as NEFA, beta-hydroxybutyrates (BHB), cholesterol, or decreased concentrations of minerals, mainly calcium, magnesium, vitamins A, E, total antioxidants as well as paraoxonase $(\mathrm{PON})$ which as a liver protein released to the blood stream may be a marker of the liver function, indicating chronic damage by decreased value (Bionaz et al. 2007). The mean PON value of $66.4 \mathrm{U} / \mathrm{ml}$ measured by the cited authors in cows at and after calving was drastically decreased in chronic liver damage and was negatively correlated with serum acute phase protein - haptoglobin ( $\mathrm{Hp}$ ). Not only hypocalcaemia with a calcium serum concentration lower than $2.2 \mathrm{mmol} / \mathrm{l}$ is often observed in cows with RP, but also other decreased minerals such as serum phosphorus and zinc concentration, increased aspartate transaminase (AST), gamma-glutamyl transferase (GGT) activity with accompanied neutropaenia were noted in these animals (Moretti et al. 2015). The cited authors suggest that neutropaenia seems to be an important co-factor connected with the pathogenesis of RP in dairy cows. Also shortage of other minerals and trace elements may cause serious disturbances of the internal homeostasis in cows (Spolders 2007).

Whitaker et al. (2005) presented normal blood serum metabolic and mineral ranges in cows as follows: $\operatorname{BHB}(0.6-1 \mathrm{mmol} / \mathrm{l})$, NEFA $(0.5-0.7 \mathrm{mmol} / \mathrm{l})$, glucose $(3-4 \mathrm{mmol} / \mathrm{l})$, urea $\mathrm{N}$ (1.7-7.0 mmol/1), albumins (30-49 g/l), magnesium $(>0.7 \mathrm{mmol} / \mathrm{l})$, phosphorus $(>1.3 \mathrm{mmol} / \mathrm{l})$. Typical blood serum ranges for other important indices, such as calcium (2.4-3.0 mmol/l, AST (68-100 mmol/l), GGT (22-64 U/l), total cholesterol (1.8-5.2 $\mathrm{mmol} / \mathrm{l})$, triglicerydes $(0.1-0.2 \mathrm{mmol} / \mathrm{l})$, vitamin A $(30 \mathrm{ng} / \mathrm{dl})$, vitamin E $(7-21 \mu \mathrm{mol} / \mathrm{l})$, vitamin D (80 ng/dl), vitamin B12 (35 ng/dl), vitamin C (120 ng/dl) may be helpful during potential biochemical blood metabolic monitoring in dairy cows in terms of RP (Winnicka 2011). The above mentioned indices and other more important biochemical properties of the blood serum and their physiological ranges in cows are presented in Table 1. In particular, vitamin $\mathrm{E}$ allows for the production of adequate amounts peroxides and cytokines (interleukin IL-1) by neutrophils, while copper is essential for normal phagocytosis (Spears and Weiss 2008). The values of presented blood properties are directly associated with metabolic functions in dairy cows, the level of milk production, fertility and quality of the course of calving.

The oxidative stress and its immune-suppressive consequences also in relation to RP are caused not only by deficiency of vitamins $\mathrm{E}$ and A, but also by a lack of micro- or macro-elements such as selenium, zinc, copper, and chromium in diet (Kendall and Bone 2006). The cited authors presented normal limits for the most important trace elements in serum (S) or in full blood (FB): selenium ( $>110 \mu \mathrm{g} / \mathrm{l} \mathrm{FB})$, zinc $(80-120 \mu \mathrm{g} / \mathrm{dl} \mathrm{FB})$, manganese $(5-6 \mu \mathrm{g} / \mathrm{l} \mathrm{FB})$, copper $(9.2 \mu \mathrm{mol} / 1 \mathrm{~S})$, iodine $(3-6 \mu \mathrm{g} / \mathrm{l} \mathrm{S})$, molybdenum $(>1.1 \mu \mathrm{mol} / 1 \mathrm{~S})$, iron $(25-35 \mu \mathrm{mol} / 1 \mathrm{~S})$, cobalt $(0.38-1.85 \mu \mathrm{mol} / 1 \mathrm{~S})$. Vitamins and minerals 
Table 1. More important blood serum indices in the periparturient period and their physiological range in cows.

\begin{tabular}{|c|c|c|}
\hline Blood serum index & Physiological range & According to the author \\
\hline Cortisol & $5 \mathrm{ng} / \mathrm{ml}-10 \mathrm{ng} / \mathrm{ml}$ & Mormede et al. (2007) \\
\hline Adrenalin & around $60 \mathrm{pg} / \mathrm{ml}$ & Lamp et al. (2015) \\
\hline PON - paraoxonase & around $66.4 \mathrm{U} / \mathrm{ml}$ & Bionaz et al. (2007) \\
\hline Haptoglobin & $0.5-0.7 \mathrm{~g} / 1$ & Trevisi et al. (2012) \\
\hline $\mathrm{BHB}$ & $0.6-1 \mathrm{mmol} / 1$ & Whitaker et al. (2005) \\
\hline NEFA & $0.5-0.7 \mathrm{mmol} / 1$ & \\
\hline Glucose & $3-4 \mathrm{mmol} / 1$ & \\
\hline Urea N & $1.7-7.0 \mathrm{mmol} / \mathrm{l}$ & \\
\hline Albumin & $30-49 \mathrm{~g} / 1$ & \\
\hline Magnesium & above $0.7 \mathrm{mmol} / 1$ & \\
\hline Phosphorus & above $1.3 \mathrm{mmol} / 1$ & \\
\hline Calcium & $2.4-3.0 \mathrm{mmol} / 1$ & Winnicka (2011) \\
\hline AST & $68-100 \mathrm{mmol} / 1$ & \\
\hline GGT & 22-64 U/1 & \\
\hline Total cholesterol & $1.8-5.2 \mathrm{mmol} / 1$ & \\
\hline Triglicerydes & $0.1-0.2 \mathrm{mmol} / 1$ & \\
\hline Vitamin A & around $30 \mathrm{ng} / \mathrm{dl}$ & \\
\hline Vitamin E & $7-21 \mu \mathrm{mol} / 1$ & \\
\hline Vitamin D & around $80 \mathrm{ng} / \mathrm{dl}$ & \\
\hline Vitamin B12 & around $35 \mathrm{ng} / \mathrm{dl}$ & \\
\hline Vitamin C & $120(\mathrm{ng} / \mathrm{dl})$ & \\
\hline Copper around & $9.2 \mu \mathrm{mol} / 1$ & Kendall and Bone (2006) \\
\hline Iron & $25-35 \mu \mathrm{mol} / 1$ & \\
\hline Cobalt & $0.38-1.85 \mu \mathrm{mol} / 1$ & \\
\hline Molybdenum & above $1.1 \mu \mathrm{mol} / 1$ & \\
\hline Iodine & $3-6 \mu \mathrm{g} / 1$ & \\
\hline
\end{tabular}

play an important role in stress and immunity, and they are also important for rejection of foetal membranes during calving.

The clinical consequences of RP in cows are often serious, requiring systemic diagnostic clinical examinations as well as laboratory tests for reproductive tract infections (deBoer et al. 2014). Hysteroscopy in cows during or after RP can be a good diagnostic tool in veterinary practice (Mordak et al. 2008). Retained placenta in cows is a very serious health problem that occurs in the last (third) phase of parturition. It has a significant negative influence on post parturient health, welfare, milk productivity, and further reproduction in the postpartum period, causing high losses (Laven and Peters 1996). There are important relationships between metabolic disorders, inflammation, immune function, RP and further consequences such as a reproductive tract disease, metritis, endometritis, infertility, and other complications (Sheldon et al. 2006; Wathers 2010; LeBlanc 2012). In such cases, it is helpful to measure acute phase proteins (APP), but even more important in bovine practice are haptoglobin $(\mathrm{Hb})$ limit $0.0-0.1 \mathrm{~g} / \mathrm{l})$, fibrinogen $(\mathrm{Fb} \mathrm{3-7} \mathrm{g} / \mathrm{l}$ ) and amyloid A (SAA limit $<0.005 \mathrm{~g} / \mathrm{l}$ ) tested in blood serum. In cows with RP on the third day after expulsion of the foetus, not only acute puerperal metritis but also an increased level of serum Hp was noted, which reached nearly $3 \mathrm{~g} / 1$ in one third of cases of RP (mean $2.48 \mathrm{~g} / \mathrm{l}$ ) (Mordak 2008, 2009). Haptoglobin may be a non-specific but important marker for monitoring the calving time. In normal conditions, its serum blood levels were observed 
at around $0.5-0.7 \mathrm{~g} / \mathrm{l}$ (Trevisi et al. 2012). In other studies, the periparturient metabolic stress indicated by elevated BHB ( $\geq 1.2 \mathrm{mmol} / \mathrm{l})$ at 5 days in milk ( 5 DIM) was associated with elevated serum haptoglobin $(2.39-2.87 \mathrm{~g} / 1)$, but in contrast, elevated NEFA $(\geq 0.6$ $\mathrm{mmol} / \mathrm{l}$ ) at 2 DIM was not a risk factor for elevated $\mathrm{Hp}$ (Pohl et al. 2015). Moreover, in primiparous cows a higher median of serum haptoglobin concentration $(2.49 \mathrm{~g} / \mathrm{l})$ was observed than in multiparous cows $(1.4 \mathrm{~g} / \mathrm{l})$ at 5 DIM. The diagnostic monitoring of blood in cows may be performed periodically, but it may be late in relation to manifested clinical signs and occurrence of different nutritional health problems in the periparturient period as well as RP. Modern management in bovine practice requires constant daily clinical and laboratory monitoring of the health and metabolism in dairy cows especially with the use of new diagnostic methods involving also laser techniques Vis/NIS - Visible Near Infrared Spectroscopy for milk (Aernouts et al. 2011; Banias and Hebrinek 2013).

\section{Directions for nutritional and other corrective actions}

The prevention of metabolic disorders in cows involves all the methods that farmers can use to eliminate and minimize potential metabolic cases of RP. A balanced diet with adequate amounts of energy, proteins and minerals, antioxidants and peNDF in the dry period is most important for optimum welfare, health, and immune status in dairy cows (LeBlanc et al. 2004; Goof 2006). Also nutritional prophylaxis during the periparturient period as well as clinical and laboratory monitoring of dairy cows has a fundamental role in herds (Mordak and Nicpoń 2006; Illek et al 2010; Moretti et al. 2015). Energy imbalances should be corrected because they have a very negative influence on the course of the periparturient period and its immunity Rabelo et al. (2005). Energy deficiency in the diet before calving can lead to decreased serum concentration of glucose and insulin concentrations and as a consequence to lipolysis of body fat, increased serum NEFA concentration, increased hepatic supply of fatty acids, their esterification and elevated, even several times higher, pathological deposition in the form of triglycerides (TG) in the liver, finally leading to fatty liver complex and ketosis. Reduction of the negative energy balance is fundamental in the prevention of fatty liver. This can be achieved by avoiding fatty cattle, unbalanced feeds and environmental stress (Waters 2010).

Cows should enter the dry period with a body condition score (BCS) around 3-3.5. Thin cows with the BCS around 2.5 can be fed additional energy during the dry period to increase condition. Over-conditioned cattle $(\mathrm{BCS}>4.0)$ should not be restricted in feeding because this would promote fat mobilization from adipose tissue and elevate blood and liver TG. Prevention of fatty liver involves nutritional strategies for elimination or reduction of negative energy balance after calving and management with shortening the dry period length (Grummer 2008; LeBlanc 2013). According to the cited authors, a higher concentration of energy in the cows' diet several weeks before calving may be provided by the addition of fat or more energetic feeds. Glucose or glucose precursors (propylene glycol) are effective in the prevention or treatment of this energetic imbalance because they may cause an insulin response. Insulin is an antilipolytic enzyme and decreases lipid mobilization from adipose tissue. Glucagon stimulates glycogenolysis, gluconeogenesis, and insulin production and is effective at reducing fatty liver. Choline or methionine which increase the hepatic secretion of very low density lipoproteins (VLDL) in the liver can be added to the diet as a metabolic protectants, reducing the NEFA serum level and liver accumulation of TG in the liver in periparturient cows (Kudrna et al. 2009; Cermakova et al. 2012). Periparturient hypocalcaemia is also connected with metabolic processes because low calcium concentration inhibits the secretion of insulin, reducing the glucose supply of tissues (Lucy 2006). Reduced glucose supply induces lipolysis, causing negative energy balance, metabolic stress, immune suppression and ketosis. Low concentration of glucose and calcium inside smooth muscle cells causes hypotony or atony of the 
reproductive and digestive tract. Adrenalin released at this time enhances the reduction of this smooth muscle contractility. Hypocalcaemia is often observed when cows excrete more calcium in milk than they receive from the diet and from their own bones. The serum calcium limit depends on other factors such as adequate levels of the parathyroid hormone (PTH) produced by the parathyroid gland (under the control of serum calcium activity) and vitamin D3 (Kimura et al. 2006). Because cows with RP often have lower serum levels of calcium, magnesium and other elements in comparison to healthy cows, they should receive adequate supplementation in diet (Mee 2004). Vitamins and other trace elements should be assessed under diagnostic measurement with the use of blood profiles. For reduction of oxidative stress and its immune-suppressive consequences, vitamins E and A, and microor macro-elements such as selenium, zinc, copper, and chromium should be supplemented (Spolders 2007). Because diagnostics of the blood concentrations of vitamins and trace elements is very difficult and relatively expensive in bovine practice, different strategies for oral or intramuscular supplementation are often used (Abdelhameed et al. 2009). The following detailed daily dietary requirements in cows for copper $8-12 \mathrm{mg} / \mathrm{kg}$ selenium 0.3 $\mathrm{mg} / \mathrm{kg}$, zinc $40-45 \mathrm{mg} / \mathrm{kg}$, manganese $20-25 \mathrm{mg} / \mathrm{kg}$, iron $50 \mathrm{mg} / \mathrm{kg}$, iodine $0.5-0.8 \mathrm{mg} / \mathrm{kg}$, molybdenum $0.5-1.0 \mathrm{mg} / \mathrm{kg}$, cobalt $0.07-0.1 \mathrm{mg} / \mathrm{kg}$ in dry matter were presented in the study by Kendal and Bone (2006).

For the nutritional support of immune functions in cows and other ruminants, probiotics or prebiotics with the use of the cultures Enterococcus faecium or Saccharomyces cerevisiae were used with positive clinical results (Emmanuel et al. 2006; Milewski and Sobiech 2009; Milewski et al. 2010). These cultures as a diet supplement stimulate the local and general immunity by immune modulation of the digestive tract mucosal immune system and mucosal associated lymphatic tissue (MALT) and by activation of macrophages to increased phagocytosis of pathogens and mycotoxins (Wold 2001; Wilde 2005).

Apart from the nutritional management and strategy on problematic dairy farms, other methods of RP prevention are used, such as improving animal hygiene during calving, reducing stress, infections, idiopathic factors, as well as veterinary support of the parturition by the use of prostaglandin PGF2 $\alpha$ or oxytocin (Laven 1998; Abdelhameed et al. 2009). Lysozyme dimer - immune modulator was shown beneficial in cows in relation to RP when given several days before calving (Dembiński and Bronicki 1999) or when administered immediately after expulsion of the foetus during calving (Mordak 2011). Lysozyme dimer acts as a symptomatic drug and it does not eliminate the primary causes of RP in cows, however, this drug is beneficial to support the immune rejection of foetal membranes, activating the proliferation of different types of leukocytes such as neutrophils and lymphocytes, and the production of important cytokines that are suppressed by cortisol during stress (Kiczka 1994).

Symptomatic prophylaxis of RP caused by metabolic stress in dairy cows may be implemented during parturition not only with the use of immune modulators, but also by the use of beta-adrenergic blockers, which can reduce the effect of adrenalin. Beta blockers can be used in cows to protect the uterus from atony or hypotony caused by increased production of adrenalin due to stress, but they may be ineffective during severe hypocalcaemia, because a lack of calcium in the uterine smooth muscles make it impossible for these muscles to contract. Maintaining normal uterine motility during parturition with the use of the beta blocker propranolol was shown to be effective for the prevention of RP (Mordak 1991). Other beta-adrenergic blocking agent such as carazolol was shown to be effective for prevention and therapy of RP as well as during the therapy of postpartum metritis and delayed uterine involution, especially also given in combination with other drugs such as PGF2 $\alpha$ and antibiotics (Bademkiran and Kaya 2006). Health management of the periparturient period in relation to milk production, reproduction of dairy cows 
as well as metabolic disorders (negative energy balance, ketosis or hypocalcaemia) and depressed immune functions are essential on modern farms (LeBlanc 2010, 2013).

\section{References}

Abdelhameed AR, Ahmed WM, El Ekhnawy KI, El Khadrawy HH 2009: Strategy trials for prevention of retained fetal membranes in Friesian herds in Egypt. Global Vet 3: 63-68

Aernouts B, Polshn E, Lammertyn J, Saeys W 2011: Visible and near-infrared spectroscopic analysis of raw milk for cow health monitoring: reflectance or transmittance? J Dairy Sci 94: 5315-5329

Bademkiran S, Kaya HH 2006: Comparison of the betareceptor blockers (carazolol) and PGF2 $\alpha$ to prevent the retained placenta in cows due to dystocia Istambul Univ J Fac Vet Med 32: 69-79

Baines JR, Herbrink J 2013: Online milk analysis. Cattle Pract 21: 218-22116

Beagley JC, Whitman KJ, Baptiste KE, Scherzer J 2010: Physiology and treatment of retained fetal membranes in cattle J Vet intern Med 24: 261-268

Bionaz E, Trevisi E, Calamari L, Librandi F, Ferrari A, Bertoni G 2007: Plasma paraoxonase, health, inflammatory conditions and liver function in transition dairy cows. J Dairy Sci 90: 1740-1750

Cai TQ, Weston PG, Lund LA, Brodie B, McKenna, DJ, Wagner WCI 2002: Association between neutrophil function and periparturient disorders in cows. Am J Vet Res 55: 934-943

Cermakova J, Kudrina, V, Illek, J, Blazkova K, Haman J, 2012: Effects of a rumen-protected form of methionine and a methionine analogue on the lactation perfomance of dairy cows. Czech J Anim Sci 57: 410-419

Chapinal N, Carson ME, Duffield TF, Capel M, Godden S, Overton M, Santos JEP, LeBlanc SJ 2011: The association of serum metabolites with clinical disease during the transition period. J Dairy Sci 94: 4897-4903

Civelek T, Celik HA, Avci G, Cingi CC 2008: Effects of dystocia on plasma cortisol and cholesterol levels in Holstein hefers and their newborn calves. Bull Vet Inst Pulavy 52: 649-654

Davies CJ, Hill JR, Edwards JL, Schrick FN, Fisher PJ, Eldridge JA, Schlafer DH 2004: Major histocompatibility complex antigen expression on the bovine placenta: its relationship to abnormal pregnancies and retained placenta. Anim Reprod Sci 82-83: 267-280

Davies CJ, Eldridge JA, Fisher PJ, Schlafer DH 2006: Evidence for expression of both classical and nonclassical major histocompatibility complex class I genes in bovine trophoblast cells. Am J Reprod Immunol 55: $188-200$

deBoer MW, LeBlanc SJ, Dubuc J, Meier S, Heuwieser W, Arlt S, Gilbert RO, McDougall S 2014: Invited review: Systemic review of diagnostic test for reproductive-tract infection and inflammation in dairy cows J Dairy Sci 97: 3983-3999

Dembiński Z, Bronicki M 1999: Lydium KLP (dimer of lisozyme) in prophylaxis of retention secundinarum in cows. Proc. $1^{\text {st }}$ Middle -European Buiatric Congress. Balatonfured, Hungary: pp. 210-21315

Emmanuel DGV, Jafari A, Beauchemin KA, Leedle JAZ, Ametaj BN 2007: Feeding live cultures of Enterococcus faecium and Saccharomyces cerevisiae induces and inflammatory response in feedlot steers. J Anim Sci $\mathbf{8 5}$ : 233-239

Esposito G, Irons PC, Webb EC, Chapwanya A 2014: Interactions between negative energy balance, metabolic diseases, uterine health and immune response in transition dairy cows Anim Reprod Sci 144: 60-71

Goff JP, Horst RL 1997: Physiological changes at parturition and their relationship to metabolic disorders. J Dairy Sci 80: $1260-1268$

Goff J P 2006: Immune suppression around the time of calving and the impact of metabolic disease. XXV Jubilee World Buiatrics Congress Budapest, Hungary. Hungarian Vet J 130 Suppl 1: 39-42

Goff JP 2006: Major advances in our understanding of nutritional influence on bovine health. J Dairy Sci 89: 1292-1301

Gray CP, George TDSt, Jonsson NN 2007: Milk fever in dairy cattle: a novel hypothesis for immune mediated etiology. Cattle Pract 15: 277-282

Grummer RR 2008: Nutritional and management strategies for the prevention of fatty liver in dairy cattle. Vet J 176: $10-20$

Hill JR, Schlafer DH, Fisher PJ, Davies CJ 2002: Abnormal expression of trophoblast major histocompatibility complex class I antigens in cloned bovine pregnancies is associated with a pronounced endometrial lymphocytic response. Biol Reprod 67: 55-63

Joosten I, Hensen EJ 1992: Retained placenta an immunological approach. Anim Reprod Sci 28: 451-461

Illek J, Kumprechtova D, Matejicek M, Vlcek M 2009: Metabolic profile in high-producing dairy cows in different phases of the calving-to-calving interval. Folia Vet 1: 73

Horst RL, Jorgensen NA 1982: Elevated plasma cortisol during induced and spontaneous hypocalcaemia in ruminants. J Dairy Sci 65: 2332-2337

Horta AEM, Chassange M, Brachart MP 1986: Prostaglandin F2 alpha and prostacyclin inbalance in cows with placental retention - new findings. Annal Recher Vet 17: 395-400

Jahan N, Minuti A, Trevisi E 2015: Assessment of immune response in periparturient dairy cows using in ex vivo whole blood stimulation assay with lipopolysaccharides and carrageenan skin test. Vet Immunol and Immunopathol 165: 119-126 
Kendall NR, Bone P 2006: Fertility and trace elements-an understand problem. Cattle Pract 14: 17-22

Kiczka W 1994: From lysozyme monomer to lysozyme dimer. Proc XVII Buiatric Congress Bologna, Italy, pp. 897-900

Kimura K, Goff JP, Ir MEK, Reinhardt TA 2002: Decreased neutrophil function as a cause of retained placenta in dairy cows Am Dairy Sci 85: 544-550

Kimura K, Goff JP, Reinhardt TA, Saito S, Tyler HD 2003: Association between retained placenta and impaired neutrophil function in dairy cows. Acta Vet Scand 44 (Suppl 1): 24

Kimura K, Reinhardt TA, Goff JP 2006: Parturition and hypocalcemia blunts calcium signals and immune cells of dairy cattle. J Dairy Sci 89: 2588-2595

Kimura K, Goff JP, Kehrli ME Jr 1999: Effects of the presence mammary gland on expression of neutrophil adhesion molecules and myeloperoxidase activity in periparturient dairy cows. J Dairy Sci 82: 2385-2392

Kudrna V, Illek J, Marounek A, Ngoc AN 2009: Feeding ruminally protected methionine to pre- and postpartum dairy cows: effect on milk performance, milk composition and blood parameters. Czech J Anim Sci 54: 395-402

Lamp O, Derno M, Otten W, Mielenz M, Nürnberg G, Kuhla B 2015: Metabolic heat stress adaption in transition cows: differences in macronutrient oxidation between late-gestating and early-lactating German Holstein dairy cows. Plos One 10: e0125264

Laven RA, Peters A 1996: Bovine retained placenta: etiology, pathogenesis and economic losses. Vet Rec 139: 465-471

Laven RA 1998: Use of oxytocine to prevent retained placenta after induction with cloprostenol. Cattle Pract 6: 291-296

LeBlanc S J, Herdt TH, Seymour WM, Duffield TF, Leslie KE 2004: Peripartum serum vitamin E, retinol, and betacarotene in dairy cattle and their associations with disease. J Dairy Sci 87: 609-619

LeBlanc SJ 2010: Monitoring metabolic health of dairy cattle in transition period. J Reprod Dev 56 Suppl 1: 29-35

LeBlanc SJ 2012: Interactions of metabolism, inflammation and reproductive tract in postpartum period in dairy cattle. Reprod Domest Anim 47 Suppl 5: 18-30

LeBlanc SJ 2013: Managing transition period health for reproductive performance in dairy cows. Cattle Pract 21: 209-215

Lucy M 2008: Mechanisms linking growth hormone, insulin and reproduction: Lessons from postpartum dairy cow. Cattle Pract 14: 23-32

Martins VMV, Marques Junior AP, Vasconelos AC, Martins E, Santos RL, Lima FPC 2004: Placental maturation and expulsion in Holstein and Nelore cows. Arg Bras Med Vet Zootec 56: 157-167

McNaughton AP, Murray RD 2009: Structure and function of the bovine fetomaternal unit in relation to the causes of retained fetal membranes. Vet Rec 165: 615-622

Mee JF 2004: The role of micronutrients in bovine periparturient problems. Cattle Pract 12: 95-108

Milewski S, Sobiech P 2009: Effect of dietary supplementation with Saccharomyces cerevisiae dried yeast on milk yield, blood biochemical and haematological indices in ewes. Bull Vet Inst Pulawy 53: 753-758

Milewski S, Sobiech P, Bednarek D, Wójcik R, Małaczewska J, Zaleska B, Siwicki A 2010: Effect of oligosaccharides supplementation on the meat performance traits and selected indicators of humoral immunity in lambs. Bull Vet Inst Pulawy 54: 175-179

Miyoshi M, Sawamukai Y, Ivanaga T 2002: Reduced phagocytic activity macrophages in bovine retained placenta. Reprod Dom Anim 37: 53-56

Mordak R 1991: Clinical observations after use of propranolol in cows after calving. Now Wet 21: 26-32

Mordak R, Nicpoń J 2006: Values of some blood parameters in dairy cows before and after delivery as a diagnostic monitoring of health in herd. EJPAU 9: 1-5

Mordak R, Nicpoń J 2006: Selected blood parameters in cows at the periparturient period and increasing lactation. Med Wet 62: 1292-1294

Mordak R 2006: Usefulness of haptoglobin for monitoring the efficiency of therapy of fetal membrane retention. Med Wet 64: 434-437

Mordak R 2009: Postpartum serum concentration of haptoglobin in cows with fetal membranes retention. Cattle Pract 17: 100-102

Mordak R, Nicpoń J, Kubiak K, Jankowski M 2008: Hysteroscopy in the early postpartum period in cows. Med Wet 64: 1023-1025

Mordak R 2011: Retained fetal membranes in cows depending on the course of delivery and the use of the lysozyme dimer after expulsion of fetus. Monograph published by Wroclaw University of Environmental and Life Sciences pp. 33-39

Mordak R, Stewart PA 2015: Periparturient stress and immune suppression as a potential cause of retained placenta in highly productive dairy cows: examples of prevention. Acta Vet Scand 57: 84

Moretti P, Probo M, Morandi N, Trevisi E, Ferrari A, Minuti A, Venturini M, Paltrinieri S, Giordano A 2015: Early post-partum hematological changes in Holstein dairy cows with retained placenta. Anim Reprod Sci 152: 17-25

Mormede P, Andanson S, Aupérin B, Beerda B, Guémené D, Malmkvist J, Manteca X, Manteuffel G, Prunet P, van Reenen CG, Richard S, Veissier I 2007: Exploration of the hypothalamic-pituitary-adrenal function as a tool to evaluate animal welfare. Physiol Behav 92: 317-339 
Nordlund K 2005: Herd-based monitors and tests for dairy cow and calf problems. Cattle Practice 13: 87-92

Peter AT 2013: Bovine placenta: a review on morphology, components and defects from terminology and clinical perspectives. Theriogenol 80: 693-705

Pohl A, Burfeind O, Heuwieser W 2015: The associations between postpartum serum haptoglobin concentration and metabolic status, calving difficulties, retained fetal membranes, and metritis. J Dairy Sci 98: 4544-4551

Price PJ, Banki Z, Scheideler A, Stoiber H, Verschoor A, Sutter G, Lehmann MH 2015: Complement component $\mathrm{C} 5$ recruits neutrophils in the absence of $\mathrm{C} 3$ during respiratory infection with modified vaccinia virus Anka. J Immunol 194: 1164-1168

Rabelo E, Rexende RL, Bertics SJ, Grummer RR 2005: Effects of pre- and postfresh transition diets varying in dietary energy density on metabolic status of periparturient dairy cows. J Dairy Sci 88: 4375-4383

Saito S 2001: Cytokines cross talk between mother and the embryoplacenta. J Reprod Immunol 52: 15-33

Semacan A 2005: Liver function in cows with retained placenta. Turk J Vet Anim Sci 29: 775-778

Schlafer DH, Fisher PJ, Davies CJ 2000: Bovine placenta before and after birth. Placental development and function in health and disease. Anim Reprod Sci 60-61: 145-160

Sheldon IM, Lewis GS, LeBlanc S, Gilbert RO 2006: Defining postpartum uterine disease in cattle. Theriogenol 61: $1516-1530$

Sobiech P, Rypuła K, Wojewoda-Kotwica B, Michalski S 2010: Usefulness of calcium-magnesium products in parturientparesis in HF cows. J Elementol 15: 693-704

Spears JW, Weiss PW 2008: Role of antioxidants and trace elements in health and immunity of transition dairy cows. Vet J 176: 70-76

Spolders M 2007: New results of trace elements research in cattle. Mat. $13^{\text {th }}$ International Conference on Production Diseases in Farm Animals, Leipzig, pp. 246-272

Suthar VS, Canelas-Raposo J, Deniz A, Heuswieser W 2013: Prevalence of subclinical ketosis and relationships with postpartum diseases in European dairy cows. J Dairy Sci 96: 2925-2938

Trevisi E, Ferrari AR, Bertoni G 2008: Productive and metabolic consequences induced by the retained placenta in dairy cows. Vet Res Com 32: 363-366

Trevisi E, Amadori M, Cogrossi S, Razzuoli E, Bertoni G 2012: Metabolic stress and inflammatory response in high-yielding, periparturient dairy cows. Res Vet Sci 93: 695-704

Wathers DC 2010: Interactions between energy balance, the immune system end the reproductive tract with influence on dairy cow fertility. Cattle Pract 18: 19-26

Wathers DC, Swangchan-Uthai T, Oguejiofor CF, Cheng Z 2013: Energy balance, immune function and fertility in the postpartum dairy cow. Cattle Pract 21: 129-137

Whitaker DA, Macrae AI, Burrough E 2005: Nutrition, fertility and dairy herd productivity. Cattle Pract 13: 27-32

Winnicka A 2011: Reference values of basic laboratory tests in veterinary medicine. Edition V amended SGGW, Warsaw, pp 40-72

Wilde D 2005: Mycotoxins - are they a threat to the UK dairy industry? Cattle Pract 13: 131-133

Wold AE 2001: Immune effects of probiotics. Scand J Nutr 45: 76-85

Wooding FBP 1992: Current Topic: The synepitheliochorial placenta of ruminants. Binucleate cell fusions and hormone production. Placenta 13: 101-113 